
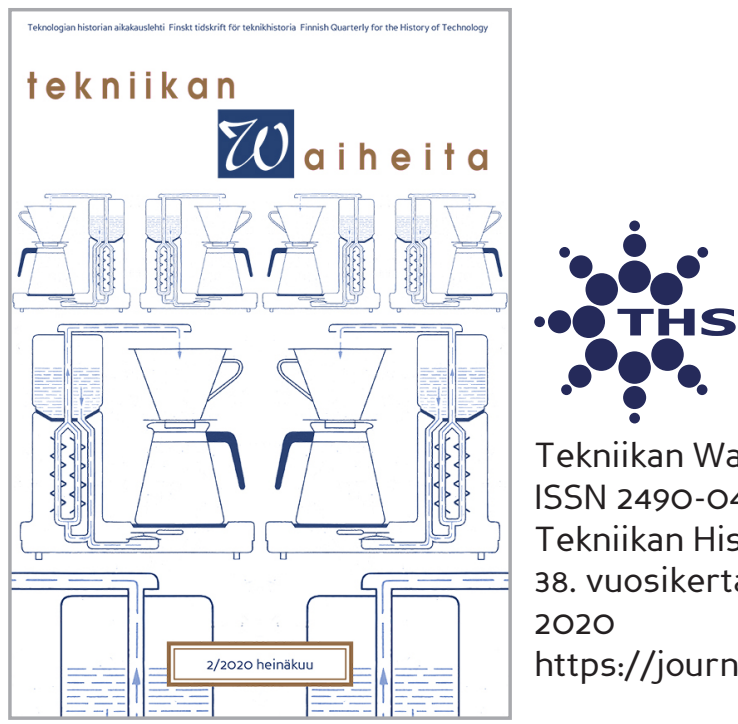

Tekniikan Waiheita

ISSN 2490-0443

Tekniikan Historian Seura ry.

38. vuosikerta:2

2020

https://journal.fi/tekniikanwaiheita

\title{
Demoskene nimettiin elävän perinnön luetteloon
}

\section{Markku Reunanen}

To cite this article: Markku Reunanen, "Demoskene nimettiin elävän perinnön luetteloon" Tekniikan Waiheita 38, no. 2 (2020): 38-40. https://dx.doi.org/10.33355/tw.96988

To link to this article: https://dx.doi.org/10.33355/tw.96988 


\title{
Demoskene nimettiin elävän perinnön luetteloon
}

\author{
Markku Reunanen'
}

Demoskene (engl. demoscene) on kansainvälinen yhteisö, joka on keskittynyt demojen, ohjelmointia, grafiikkaa ja ääntä luovasti yhdistävien reaaliaikaisten audiovisuaalisten esitysten tekemiseen. Se syntyi 1980-luvun puolivälissä kotitietokoneiden yleistymisen myötä ja on säilynyt elinvoimaisena näihin päiviin saakka, mikä tekee siitä erään vanhimmista digitaalisen kulttuurin muodoista. Maantieteellisesti harrastus on keskittynyt Eurooppaan, ja Suomi on ollut eräs aktiivisimpia demomaita etenkin väkilukuun suhteutettuna.

Opetus- ja kulttuuriministeriö nimesi huhtikuussa 2020 demoskenen Elävän perinnön kansalliseen luetteloon ensimmäisenä digitaalisena harrastuskulttuurina, mikä on samalla sekä merkittävä tunnustus itse yhteisölle että todiste elävän perinnön monimuotoisuudesta - samalla hakukierroksella luetteloon lisättiin myös vuosisataisia traditioita, kuten kanteleen soitto ja rakennus. Hakemuksen hyväksyminen herätti mielenkiintoa maailmanlaajuisestikin, sillä digitaalisen kulttuurin virallinen tunnustaminen kulttuuriperinnöksi on vähintään harvinaislaatuinen, jollei jopa ainutlaatuinen saavutus.

Suomen hakemuksen takana oli Suomen pelimuseon koordinoima työryhmä, joka koostui niin tutkijoista kuin skeneaktiiveistakin. Heikki Jungman, Niklas Nylund ja Jukka O. Kauppinen huolehtivat etenkin viestinnästä ja hakuprosessiin liittyvistä tehtävistä, kun taas Satu Haapakoski toimi aktiivisesti harrastajarajapinnassa, keräten skenerien itsensä näkemyksiä yhteisön olemuksesta ja merkityksistä. Itse osallistuin hankkeeseen kirjoittamalla varsinaisen hakemustekstin sekä hankkimalla valtaosan tukijayhteisöistä, joita saatiin mukaan kaikkiaan neljätoista. Lisäksi saamme kiittää lukuisia muita hankkeeseen osallistuneita muun muassa kommentoinnista, kielenhuollosta ja tiedonlevityksestä.

Elävän perinnön kansalliseen luetteloon hakeminen ei ole kohtuuttoman työlästä. Hakijat kirjoittavat ensin avoimeen Wikiin lyhyehkön artikkelin, joka noudattelee varsinaisen hakemuksen muotoa: kuka perinnettä ylläpitää, mitä se sisältää, minne se sijoittuu, mikä on sen historia, ja miltä sen tulevaisuus vaikuttaa? Lisäksi tarvitaan luettelot hanketta tukevista yhteisöistä sekä aihetta käsittelevästä kirjallisuudesta. Eräänä ohjenuoranani pidin sitä, että tekstin tulisi edustaa suomalaista demoskeneä kokonaisuutena, kuuluisimpien ryhmien ja teosten maineen pönkittämisen sijaan. Tiesin jo vanhastaan skenen olevan kriittinen yleisö, eikä soraääniltä tälläkään kertaa vältytty, mutta kaikkiaan palaute on ollut positiivista.

Satu Haapakosken vuonna 2019 verkossa tekemä taustatutkimus paljasti, kuinka merkittävää osaa demoskene näyttelee monen harrastajan elämässä. Yhteisöä kuvattiin muun muassa "elämäksi", "luoviksi mieliksi, jotka osoittavat todellista intohimoa" sekä "yhdeksi syyksi elää". Sosiaaliset seikat, kuten pitkään kestävät ystävyyssuhteet, nousivat nekin esiin kyselyn vastauksissa.

Suomen Akatemian rahoittama Pelikulttuurien tutkimuksen huippuyksikkö järjesti Pelimuseolla 18-19. lokakuuta 2019 Collaborative Game Histories -seminaarin. Demoskene oli eräs näkyvimmistä teemoista, ja sitä käsiteltiin sekä esityksissä että omassa paneelikeskustelussaan. Seminaari oli samalla myös ensimmäinen tilaisuus, jossa esiteltiin hakemuksen alustava versio, jota yleisö sai vuorovaikutteisesti muokata. Ehdotuksia tulikin varsin

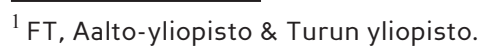




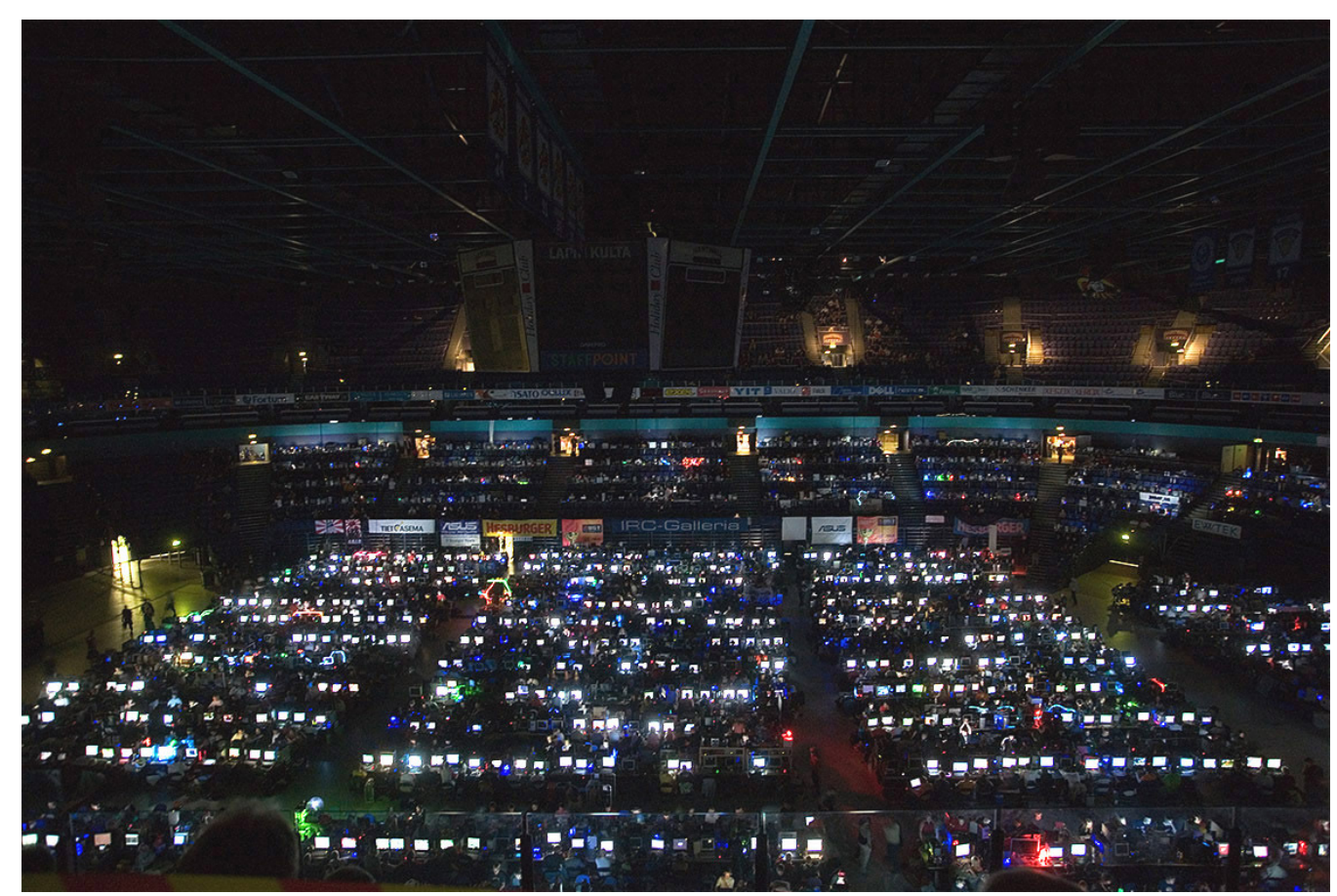

Kuva 1. Assembly 2006. Kuva: Susanna Viljanmaa.

runsaasti, ja niiden perusteella tekstiä kohennettiin monessa suhteessa. Ennen hakemuksen lähettämistä myös harrastajille tarjottiin vielä mahdollisuus kommentoida tekstiä, jotta se edustaisi yhteisöä mahdollisimman uskollisesti.

Kotimainen ponnistuksemme on osa laajempaa, Andreas Langen ja Tobias Kopkan luotsaamaa Art of Coding -hanketta, jonka lopullisena tavoitteena on saada demoskene Unescon aineettoman kulttuuriperinnön kansainväliseen luetteloon. Saksan kansallinen hakemus eteni juuri hiljattain osavaltiotasolta jatkoon, mutta käsittelyprosessi on täkäläiseen verrattuna mutkikkaampi ja hitaampi, joten kansallisen tason päätöstä täytyy odotella ensi vuoteen saakka. Muualla ollaan tiettävästi vielä lähtökuopissa, lukuun ottamatta Sveitsiä, jonka hakemus on jo edennyt pitkälle - toivomme tietysti, että Suomen menestys innostaa muita ja tasoittaa heidän tietään.

\section{Lisätietoja}

Hakemusteksti, https://wiki.aineetonkulttuuriperinto.fi/wiki/Demoskene

Museoviraston tiedote, https://www.museovirasto.fi/fi/ajankohtaista/demoskene-sahansoitto-ja-romanien-hevostaidot-elavan-perinnon-kansalliseen-luetteloon-12-uutta-kohdetta

Art of Coding -hanke, http:/ / demoscene-the-art-of-coding.net/ 